\title{
A Debreceni Helyi Vasút és a Debrecen-Nyírbátor Vasút Részvénytársaság bombakárai 1944. június 2-án
}

\author{
Bombing damage of the Debrecen Local Railway \\ and the Debrecen Nyírbátor Railway Public Limited Company \\ on 2 June 1944
}

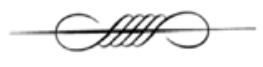

\begin{abstract}
Debrecen's marshalling yard and railway facilities were dealt with an over whelming air raid by the US Air Force on 2 June 1944. As the result of the attack, the town also sustained major damage. However, out of the keyparts of the industrial and transport infrastructure, only Debrecen's transport company sustained irreparable damage. In my study, with the help of archive resources, I represent the lines and sites of the Debrecen Local Railway and the Debrecen Nyírbátor Railway Public Limited Company, the catastrophic bombing damage of 2 June 1944, the aftermath of the bombing, and the steps take into restart transport.
\end{abstract}

\section{KEYWORDS}

Debrecen, Hungary, World War 2, air war, air raid, Frantic Joe, shuttlebombing operations, railroads, marshalling yard, DHV, DNyBV, tram

DOI 10.14232/belv.2019.2.2 https://doi.org/10.14232/belv.2019.2.2

Cikkre való hivatkozás / How to cite this article: Horváth Attila (2019): A Debreceni Helyi Vasút és a Debrecen-Nyírbátor Vasút Részvénytársaság bombakárai 1944. június 2-án. Belvedere Meridionale 31. évf. 2. sz. 31-42. pp. 
(Creative Commons) Nevezd meg! - Így add tovább! 4.0 (CC BY-SA 4.0)

(Creative Commons) Attribution-ShareAlike 4.0 International (CC BY-SA 4.0)

www.belvedere-meridionale.hu

Magyarország közlekedési csomópontjai ellen az amerikai légierő 1944. június 2-án elsöprő erejü támadást indított. Ezen a napon az amerikai 15. Légi Hadsereg kötelékébe tartozó bombázókötelékek számos kelet-magyarországi célpont mellett Debrecen vasútállomását és mühelytelepét is támadták. A légitámadás eredményeképpen a várost hatalmas károk érték, ám a jelentősebb ipari és közlekedési infrastruktúra létesítményei közül javíthatatlan károk csak Debrecen város közlekedési vállalatát érték. A cég történetéről eddig több publikáció látott napvilágot, ám azok a légitámadásról kevés tényt közölnek, pedig arról kutatható források állnak rendelkezésre.

Tanulmányomban ezeket a levéltári forrásokat használtam fel. Segítségükkel röviden bemutatásra kerül a közlekedési vállalatok vonalhálózata és telephelyei. A tanulmány kiemelt céljaként foglalkozik a vállalatok tulajdonában lévő ingatlanok, eszközök és berendezések 1944. június 2-án elszenvedett katasztrofális mértékű káraival. Ezen túlmenően bemutatásra kerülnek a bombázás utóhatásai és a közlekedés újraindításának lépései.

\section{DEBRECEN VÁROS TÖMEGKÖZLEKEDÉSÉNEK FEJLŐDÉSE ÉS A VÁLLALATOK TELEPHELYEI.}

Debrecenben a villamos előképének tekinthető, gőzüzemű vontatással megoldott személyszállítás az Osztrák-Magyar Monarchia területén elsőként, 1884. október 2-án kezdődhetett meg. Már ezt megelőzően megalakult a Debreceni Helyi Vasút Részvénytársaság (továbbiakban DHV), mely a teljes körü üzemeltetést magára vállalta. A tényleges villamosközlekedés az országban hatodikként, 1911. március 16-án indulhatott meg. A szerteágazó villamos vonalakról ${ }^{1}$ a szerelvények - miután rácsatlakoztak a Nagyállomás és a Nagyerdő között közlekedő fővonalra - a Késes utcán ${ }^{2}$ keresztül tudtak eljutni a Salétrom utcai kocsiszínbe. A DHV ezen a telepen osztozott meg a Debrecen-Nyírbátori Vasút Részvénytársaság (továbbiakban DNyBV) létesítményeivel és gördülőanyagával. Ez a vasúttársaság a Nagyállomásról indította szerelvényeit, melyek a Salétrom és Nyugati utcák érintésével az akkor még létező Debrecen-vásártéri állomást útba ejtve haladtak tovább a Nyulason át Hajdúsámson, majd Nyírbátor irányába. Szerelvényeik személyszállításra és teherszállításra egyaránt alkalmasak voltak.

\footnotetext{
${ }^{1}$ A városban bár 11 viszonylat közlekedett, ám azok négy vonalon osztoztak meg különböző helyeken létesített végállomásokkal. A fővonal a Pályaudvartól a Klinikákig volt használatban, a Hatvan utcai vonal a Nagytemplom elől indult a Nyulas irányába, a Csapó utcai vonal a Csapó utca elejéről a Köztemető felé, míg a Kossuth utcai vonal a Kossuth utcától a Vágóhíd irányába közlekedett. Debreceni Közlekedési Vállalat Művezetői kézikönyv.

${ }^{2}$ A Késes utca napjainkban már nem létezik. Egykor az Erzsébet és Ispotály utcák között helyezkedett el, mindkét oldalán kisméretű telkekkel. Az 1944-es szövetséges légitámadások gyakorlatilag megsemmisítették, helyén az 1960-as évek városrendezésekor lakótelepet létesítettek. A remízbe gördülő villamosok napjainkban az egykori utcával párhuzamos Ispotály utcán közlekednek.

${ }^{3}$ Ma a Segner téri társasházak vannak az egykori állomás helyén.
} 
A két vállalatnak nemcsak a telephelye volt közös, hanem az igazgatósági épülete is. A két cég székhelye nem a telepen, hanem attól távolabb, a Petőfi tér 14. szám alatt volt. Ez a kétszintes épület, mely egyebek közt lakást, kapcsolótáblát, jegypénztárt és irodákat is tartalmazott, a hozzátartozó gazdasági építményekkel együtt pontosan a Nagyállomás felvételi épülete előtt állt. A székház szomszédja a légitámadásban később megsemmisült Ispotály templom ${ }^{4}$ volt.

A közlekedés napi lebonyolításához használt telep a Nagyállomás felvételi épületétől légvonalban hozzávetőlegesen 700 méter távolságban helyezkedett el. Ez nem volt véletlen, hiszen a kor városrendezési elveinek megfelelően az ipari és egyéb gazdasági létesítményeket igyekeztek a város köldökzsinórjának tekintett vasúttól nem túl nagy távolságra telepíteni. ${ }^{5}$ A közlekedési vállalat épületeinek napjainkban is helyet adó telek szorosan beékelődött a Hajlított Bútorgyár mellé, míg észak felől a Szoboszlói úton lévő egykori Salétrom laktanya határolta. A másik két irányból családi házas lakóövezetek, keletről a Salétrom utca, nyugati irányból a Keleti sor ölelték körbe a telephelyet.

\section{A DEBRECEN ELLENI LÉGITÁMADÁS ${ }^{6}$}

1944. június 2-ának napfényes reggelén már öt perccel nyolc óra előtt beérkeztek a jelentések az első bombázókötelékekről a budapesti légvédelmi központba. 8 óra 7 perckor a magyar rádió megszakította adását, és felhívta a lakosság figyelmét az ellenséges repülők berepülésére. Ezt követően a légoltalmi körzetekben fokozatosan elrendelték a légiriadót. A rádióadás megszakítása után öt perccel a szegedi, 8 óra 15 perckor a földvári, 8 óra 16 perckor a budapesti és a szolnoki körzeteket riasztották. Nem sokkal ezután riasztották az többi Duna-Tisza-közén lévő és a tiszántúli körzeteket. A DHV 1944. június 19-én keltezett kárjelentésében az alábbi mondat szerepel: „A forgalmista emlékezete szerint körülbelül 8 óra és 8 óra 15 perc között szakitották meg a müsort annak jeléül, hogy berepülési veszély van.” A szolgálattevő tehát - kinek feljegyzései a romok alatt rekedtek - helyesen emlékezett. ${ }^{7}$

Debrecen fölé érve 8 óra 46 perckor kezdte meg a bombázást az amerikai 5. bombázó wing (ezred) első hulláma. A légiriadó és a bombázás között eltelt időt Debrecen város légoltalmi parancsnoka által készített jelentés ${ }^{8} 24$ percre teszi. Ez azt jelenti, hogy a légiriadót nem a jelentésben közölt 8 óra 30 perckor, hanem 8 óra 22 perckor rendelték el. A légiriadó végét jeltő sziréna viszont majd csak 10 óra 42 perckor szólalt meg. Ebből következően az egymás után, déli irányból érkező bombázókötelékek 1 óra 56 percen keresztül támadták Debrecent. Az észak felé áthaladó amerikai kötelékek által ledobott bombaszőnyeg a gépek haladási irányában „gördült le”, ennek következtében a célpontként kijelölt Nagyállomás területétől északra elhelyezkedő városrészek is a támadás áldozatává váltak.

\footnotetext{
${ }^{4}$ A Debrecent ért 1944. június 2-i légitámadás kárhelyeiről készített fényképfelvételek közül talán a legismertebb ezt a templomot ábrázolja félig hiányzó tornyával.

${ }^{5}$ Debrecen város korabeli térképét szemlélve látható, hogy néhány malmot és az alapanyag lelőhelyekhez települt téglagyárakat leszámítva a város északi kétharmadán nem találunk fontosabb ipari üzemet. A város gyakorlatilag teljes ipari struktúrája a vasútállomást is magába foglaló alsó egyharmadon létesült.

${ }^{6}$ A Debrecen városát ért első amerikai légitámadás repüléstörténetét a rendelkezésre álló források felhasználásával napjainkra sikerült feltárni. A Frantic hadműveletek nyitányaként végrehajtott bevetésről jelen tanulmány szerzőjének kötetét lehet az érdeklődők figyelmébe ajánlani. A témához további adalékokkal szolgál Oláh András Pál történész Szolnok elleni légitámadásról és a szövetséges légi felderítésről szóló tanulmányai.

${ }^{7}$ MNL-HBML XI.105/a 38. cs.

${ }^{8}$ MNL-HBML IV.B 1406/e. 153/1944.
} 


\section{A KÖZLEKEDÉSI VÁLLALATOK ÁLTAL ELSZENVEDETT BOMBAKÁROK 1944. JÚNIUS 2-ÁN}

A Petőfi tér nyugati oldalán álló DHV-DNyBV közös igazgatósági épületének semmi esélye nem volt arra, hogy „túlélje” ezt a napot. A székház főhomlokzatát egy bomba az épület alapjáig lerombolta. A robbanás az épület alatt létesített óvóhelyet is használhatatlanná tette. A megmaradó épületrész falai összerepedeztek, a mennyezeten szintén repedések éktelenkedtek. A tetőzet és a nyílászárók szintén súlyosan megrongálódtak a felrobbanó bombák által keltett lökéshullámtól és a repeszdaraboktól. Az épületben keletkezett kár mértéke elérte a 80\%-ot, összege 220800 pengőre rúgott. Az épülettől keleti irányban 15 méterre négy bomba csapódott be, déli falától 4-5 méterre egy bomba esett le. A feljegyzések szerint a keletkező bombatölcsérek átmérője nagyjából 15 méter volt, mélységét 5-6 méterre becsülték. Az igazgatósági épület udvarának a délnyugati sarkában lévő pályafenntartási bódéra egy bomba hullott le, amelytől az rommá vált. A telken lévő gazdasági építmények közül mindegyiket kisebb-nagyobb károk érték, érdekes módon egyedül a baromfiól maradt sértetlen. Az altiszti lakóépület szintén légnyomáskárt szenvedett, melynek eredményeképpen tetőcserepei szétszóródtak, üvegezése összetört, falazata megrepedt, vakolata sok helyen leomlott. A kerítés két helyen sérült meg a rázuhanó bombák robbanásának következtében. Az irodahelységekben lévő ingóságok közül megsemmisültek a telefonkészülékek a hozzájuk csatlakoztatott kapcsolótáblákkal együtt. A forgalmi irodában a Nyírbátori vasút távíró berendezései teljes egészében tönkrementek. Az összesített kár 243572 pengőt tett ki. ${ }^{9}$

Az 1944. június 2-i bombatámadás alkalmával a DHV és a DNyBV Salétrom utcai telepe gyakorlatilag megsemmisült. A 38 darab becsapódott bomba minden az üzemeltetéshez szükséges épületet megsemmisített vagy súlyosan megrongált. Kismértékü károk jobbára a telep Salétrom utca felé eső bejárati részén keletkeztek. Vakolat- és tetőfedési károk voltak a kapunál lévő kocsimesteri lakásban, a mellette álló őrbódéban, és a pályafenntartási raktárban. Ezen túlmenően egy az épület mellett felrobbant bombától súlyosan megrongálódott a létraszín és a vele összeépített tornyos-szín. Hasonló károk keletkeztek a Salétrom utcára néző üzletigazgatósági irodaépületben, melynek falazata összerepedezett, nyílászárói kimozdultak a helyükről.

A közösen használt telep nyugati irányba eső részén jóval nagyobb volt a rombolás. A DHV által használt épületek közül többszörös telitalálat következtében megsemmisült a DHV villamos kocsiszínje, melynek romjai ráadásul ki is égtek. ${ }^{10}$ A romok maguk alá temettek több villamoskocsit, valamint az összes bent lévő eszközt. A tüz pusztítása olyan mértékű volt, hogy a másnap készült szövetséges felderítő felvételen ez volt az egyetlen épület, amely még mindig sürü füstöt égnek eresztve lángolt. A romok alatt pusztult el a bent futó teljes vágányzat, a tisztító- és szerelő akna is. Csodával határos módon maradt épségben a kiégett kocsiszín mellett álló víztorony, bár annak

\footnotetext{
${ }^{9}$ MNL-OL Z 1624 38. tétel. A megmaradt épületek és épületrészek sorsa a harmadik amerikai légitámadáskor, 1944. szeptember 21-én teljesedett be. Ekkor a telken lévő összes építmény, beleértve az igazgatósági épület maradványait is, teljes egészében a földel lettek egyenlők. Az üzletigazgatóság megmaradt berendezéseivel a Széchenyi utca 13. szám alá költözött. Az igazgatóság egyéb eszközeit a Csapó utca 24. számú ingatlanba helyezték át, ez utóbbi helyen működött egyebek közt az újra megnyitott jegypénztár is.

${ }^{10}$ National Archives Reference Number 342-FH-3A05453-A52245AC.
} 
a későbbiekben nem sok hasznát vehették, mert a telep teljes vízvezeték hálózata a nyomásfokozó berendezéssel együtt szintén megsemmisült. A vízhiány miatt nem tudott megindulni a keletkezett tüzek oltása, ami nagyban hozzájárult a kocsiszín leégéséhez. A tüzoltást a szomszédban lévő Hajlított Bútorgyár udvaráról vételezett vízzel, illetve a bombatölcsérekben feltörő és összegyülő talajvízzel tudták megkezdeni.

A Keleti sor és Szoboszlói út sarkánál lévő I-es számú autóbusz garázs és garázsmesteri lak kisebb kárt szenvedett. A II-es számú autóbusz garázs falazata azonban már jelentős mértékben megsérült és tetőfedési kár is keletkezett. Csak a vakszerencsének köszönhető, hogy a II-es garázs előtt lévő üzemanyagraktár nem robbant fel. Bár közvetlen közelébe több bomba is becsapódott, a telitalálat a kutat elkerülte. Ennek köszönhetően a környezetében lévő lakóházak minden bizonnyal egy sokkal komolyabb tűzvésztől menekültek meg. A mellette álló autóbusz raktár és kovácsmühely azonban közel 90\%-os kárt szenvedett egy telitalálattól. Ugyanilyen mértékü kárt szenvedett a faraktár is, melynek falazatát a törmelék oldalirányban megnyomta. A telep közepén álló szertárépület nyugati fala beomlott, a többi pedig erősen összerepedezett."

A DNyBV épületei közül csak kis mértékben rongálódott a telep Salétrom utca felé eső részében álló várócsarnok, a felvételi épület és az állomási melléképület. Az ugyanitt fekvő áruraktár nyugati vége egy telitalálat következtében összeomlott. A telephely felső, a Keleti sor felé eső részén lévő sínautóbusz garázs 70\%-os kárt szenvedett a közeli bombabecsapódások lökéshullámai miatt. Ezek nagymértékủ falbedőlést okoztak, a mennyezet összerepedezett, a tetőzetnek pedig több mint fele odaveszett. A közelében lévő kovácsműhely szintén telitalálat következtében elpusztult. Több bombatalálatot kapott a kocsijavító műhely, emiatt háromnegyede rommá vált. A bombarobbanások következtében az épület középső része összeomlott, két szárnya pedig súlyosan megrongálódott. Hasonlóan több bomba találta el a mozdonyszínt is, amely egyben a mozdonyok fütőháza is volt. Az épület teljes egészében összedőlt, majd a romokat a keletkező tűz pusztította tovább. A fütőház melletti fordítókorong és a vízdaru kis sérülésekkel megúszta a bombatámadást. Nem így a mozdonyjavító mühely, amelyet szintén több bomba talált telibe. Az épület az előzőekhez hasonlóan szintén romokban hevert.

A két közlekedési vállalat személyi állománya is súlyos veszteségeket szenvedett. A DHV három dolgozóját vesztette el, a DNyBV alkalmazottai közül öten haltak meg szolgálati helyükön a légitámadás alatt. Rajtuk kívül öt férfi és egy női dolgozó súlyosan- egy további férfi alkalmazott könnyebben megsebesült, akiket haladéktalanul kórházba szállították.

A DHV telepen a gördülőállományban is nagy volt az anyagi kár. Öt villamos motorkocsi, egy közúti mozdony, egy sínautóbusz, két villamos pótkocsi teljesen elpusztult, megrongálódott, de javítható maradt két villamos motorkocsi, két pótkocsi és két sínautóbusz. Ezt a két sínautóbuszt sem állították a későbbiekben helyre, így a bombatámadás pontot tett a debreceni sínautóbuszok rövid életére. Kisebb mértékben rongálódott meg négy motorkocsi és négy pótkocsi, ezeknél az ablakok és a kocsik oldalai sérültek meg. A DNyBV jármüállományából öt mozdony, két személykocsi, egy fedett teherkocsi és két tartálykocsi pusztult el. Megsérült hét személykocsi, három poggyászkocsi, kilenc fedett teherkocsi, tíz tartálykocsi, négy sínautóbusz, egy motorkocsi és két pótkocsi.

${ }^{11}$ MNL-OL Z 1624 38. tétel. 
A telepen 2800 vágányfolyóméter vágányzat ment tönkre, emellett továbbá jelentősen megrongálódott a város területén 750 méter hosszban a pálya és 1600 méter hosszban a felsővezeték rendszer. A pályatest a Ferenc József úton (a mai Piac utcán) a Vármegyeháza előtt és a Petőfi téren két telitalálatot kapott, a Hunyadi és a Késes utcákon lévő vágányhálózatra szintén több bomba csapódott be, sok helyen épületek omlottak a vágányokra. Ezeknek a romoknak az eltakarítása, kiváltképpen a két utóbbi helyen több napi fáradságos munkába került. A Késes utcai áldatlan állapotokról június 19-én készült jelentés még mindig az új vágányok lefektetésének nehézségéről számolt be. ${ }^{12} \mathrm{~A}$ bombatámadás által okozott súlyos helyzetet szemléltetvén a katasztrofális károkat elszenvedő Hunyadi utcán olyan sok időbe telt a kárfelszámolás, hogy a villamosforgalom csak július 6-án (a légitámadás után több, mint egy hónappal) tudott újra a teljes vonalon megindulni. A közte eltelt időszakban a Nagyerdő felé a villamosok ingajáratban az Arany Bika szállodától a Hunyadi utcáig vitték az utasokat. A Hunyadi utcán újra meginduló villamosoknak azonban még heteken át tartó jelentős sebességkorlátozást rendeltek el, mert az általuk keltett rezgés a még álló épületmaradványokon esetleges omlást idézhetett volna elő.

Előre látható volt, hogy a korlátozottan beszerezhető építőanyagok, és az erőforrások hiánya miatt a Salétrom utcai telepen szükséges helyreállítási munkálatok csak nehezen fognak megkezdődni, illetve befejeződni. A Magyar Királyi Hadiipari Bombakárügyi Bizottság (HABOB) 1944. augusztus 3-án lezajlott tárgyalásán csak a kocsijavító műhely, a kovácsmühely, a fütőház, az áruraktár és a sínautóbusz garázs újjáépítését, míg a villamos kocsiszín alapterületének mindössze $20 \%$-ának helyreállítását engedélyezte. ${ }^{13} \mathrm{Az}$ ehhez a szükséges alapanyagokat a bizottság ki is utalta a vállalatok részére azzal a megkötéssel, hogy a faanyagot Erdély területéről szerzik majd be, és annak Debrecenbe szállítását a saját szállítókapacitásuk igénybevételével oldják meg. Az engedélyezett munkálatok el tudtak kezdődni, ám más megoldást kellett találnia a vállalatnak, hogy a zavartalan üzemet hosszabb távon fenn tudja tartani. ${ }^{14}$ Legkézenfekvőbb megoldásnak a károkat nem szenvedett északi városrész igénybevétele kínálkozott.

\section{UTószó}

A légitámadás után azt a kevés használható eszközt, ami megmaradt, a Nagyerdőben lévő Vígadó megállóhely mellé költöztették, hogy védve legyen a további rombolástól. A mühelyépületet a Vigadó melletti csónakázótó csónakházában alakították ki. A Nagyerdő fáinak természetes védelme egészen 1944. szeptember 15-ig tartott ki, amikor is az első szovjet éjszakai légitámadás alkalmával telitalálatot kapott az új mühelyépület és a környezetében lévő több más, ideiglenes jelleggel kialakított szolgálati építmény. Ezekkel az elszenvedett károkkal leállt Debrecenben

\footnotetext{
${ }^{12}$ MNL-HBML XI.105/a 38. cs.

${ }^{13}$ A DHV néhány épületet megpróbált önerőből helyreállítani vagy használható állapotba hozni. Ezek közül a szertárépület helyreállításáról maradt fent adat. A telephely területére a következő, 1944. szeptember 1-i amerikai légitámadás során újra hullott néhány bomba, amely súlyosan megrongálta a szertárépületet. Ezt követően az újabb helyreállításra már nem volt kapacitás.
}

${ }^{14}$ MNL-HBML XI.105/a 38. cs. 
a villamos és helyi vasút közlekedése. Bár a fővonalon a villamosközlekedés 1944. november 27-én, a mellékvonalakon 1944. december 9-én újra megindult, a szénhiány miatt azonban a folyamatos áramellátásról szó sem lehetett. Az áram hiánya miatt pedig gyakori járatkimaradások hátráltatták a folyamatos üzemet. A DNyBV szerelvényei 1945. január 3-án tudtak újraindulni, ami már jelentősen segítette a napi utasforgalom lebonyolítását. A folyamatos áramellátást a Debrecen város világítási vállalata csak 1947 őszétől volt képes garantálni. Debrecen villamos- és helyi vasút közlekedésének tragikus sorsára az 1944. június 2-i amerikai légitámadás volt a legnagyobb kihatással. A támadás következtében csak évekkel később, alapjaiból újjáépítve sikerült újra beindítani. ${ }^{15}$

\section{FELHASZNÁLT IRODALOM}

Balogh László - Gara Kálmán - Végh Dezső (2011): Debreceni villamoskalauz. Az elsö száz év története. Uropath Kiadó, Debrecen.

BeretVÁs KÁroly - GaRA Kálmán (2014): A múltra épült jövő. DKV Debreceni Közlekedési Zrt; Debrecen.

Debreceni Közlekedési Vállalat Müvezetői kézikönyv. Debrecen, DKV Debreceni Közlekedési Zrt; é.n. HoRvÁth AtTILA (2014): Magyarország amerikai bombázása a II. világháborúban - A Debrecen elleni első amerikai légitámadás 1944. június 2. Debrecen, Lícium-Art.

OLÁH ANDRÁS PÁL (2018): A Földközi-tengeri Szövetséges Légierő Magyarországra vonatkozó felderítése, valamint a szövetséges légitámadások általános fotókiértékelése a II. világháború idején. Belvedere Meridionale 30. évf. 1. sz. 146-168.

OLÁH ANDRÁs PÁL (2014): Újabb adalékok a Szolnok elleni 1944. június 2-i amerikai légitámadás történetéhez. Zounuk 28., a Magyar Nemzeti Levéltár Jász-Nagykun-Szolnok Megyei Levéltára évkönyve, Szolnok, 2014.

\section{Levéltári források}

MNL-OL Magyar Nemzeti Levéltár Országos Levéltára

MNL-HBML Magyar Nemzeti Levéltár Hajdú-Bihar Megyei Levéltára

\footnotetext{
${ }^{15}$ Beretvás-Gara 2014. 51.
} 


\section{MELLÉKLET}

\begin{tabular}{|l|l|l|}
\hline \multicolumn{1}{|c|}{ Viszonylat száma } & \multicolumn{1}{c|}{ Indulás helye } & \multicolumn{1}{c|}{ Véllomás } \\
\hline 1 & Pályaudvar & Klinikák-Egyetem körforgalom \\
\hline $1 \mathrm{~A}$ & Pályaudvar & Bika szálloda \\
\hline 2 & Pályaudvar & Nagyerdei fürdő \\
\hline 4 & Városháza & Közvágóhíd \\
\hline $4 \mathrm{~A}$ & Városháza & Attila tér ${ }^{16}$ \\
\hline 5 & Bika szálloda & Baromvásártér \\
\hline $5 \mathrm{~A}$ & Bika szálloda & Hortobágy malom \\
\hline 6 & Bika szálloda & Tüzérlaktanya \\
\hline $6 \mathrm{~A}$ & Bika szálloda & Apafi utca \\
\hline 7 & Bika szálloda & Köztemető \\
\hline 12 & Pályaudvar & Pallag Gazdasági Akadémia \\
\hline
\end{tabular}

1. TÁBLÁZAT Debrecen város villamoshálózata 1944 márciusában (Forrás: BALOGH-GARA-VÉGH 2011)

\begin{tabular}{|l|l|l|l|}
\hline I & Igazgatósági épület & V & Pályafenntartási bódé \\
\hline II & Tyúkól & V/a & Pályafenntartási bódé \\
\hline III & Altiszti lakóépület & VI & Pályafenntartási bódé \\
\hline III/a & Deszkabódé & VII & Pályafenntartási bódé \\
\hline III/b & Raktárhelység & VIII & Szénraktár \\
\hline IV & Tyúkól & IX & kerítések-kapuk \\
\hline
\end{tabular}

2. TÁBLÁZAT A Petöfi téri igazgatósági épület telkén lévö épületek az 1. ábrán látható számkódokkal

\begin{tabular}{|l|l|l|l|}
\hline I & Várócsarnok (a 2. ábrán nincs jelölve) & VII & Kocsijavító mühely \\
\hline II & Felvételi épület & VIII & Fűtőház \\
\hline III & Áruraktár & VIII/a & Fordítókorong \\
\hline IV & Állomási melléképület & VIII/b & Vízdaru \\
\hline V & Sínautó garázs & IX & Mozdonyjavító mühely \\
\hline VI & Kovácsmühely & & \\
\hline
\end{tabular}

3. TÁBLÁzAT A DNyBV kezelésében lévő épületek a Salétrom utcán. Feloldása a 2. ábrán látható számkódoknak

\footnotetext{
${ }^{16}$ Sportesemények alkalmával a járat végállomása a Vágóhíd utcai DVSC pálya volt. BALOGH-GARA-VÉGH 2011. 363.
} 


\begin{tabular}{|l|l|l|l|}
\hline X & Villamos kocsiszín & XXI & Garázsmester lakás \\
\hline XI & Faraktár & XXII & 2-es számú garázs \\
\hline XII & Létraszín & XXIII & Benzinkút \\
\hline XII/a & Tornyos-szín & XXIV & Raktár és kovácsmúhely \\
\hline XIII & Kocsimesteri lakóépület & XXV & Árnyékszék \\
\hline XIV & Sertés- és tyúkól & XXVI & Szertárépület \\
\hline XV & Pályafenntartási raktár & XXVI/a & Félszer \\
\hline XVI & Árnyékszék & XXVII & Víztorony (a képen XXVIII) \\
\hline XVII & Portás őrbódé & XXVII/a & Féleresz (a 2. ábrán nincs jelölve) \\
\hline XVIII & Árnyékszék & XXVIII & Üzletigazgatói iroda \\
\hline XIX & Kerítések & XXIX & Deszkabódé \\
\hline XX & 1-es számú garázs & XXX & Szerszámbódé (a 2. ábrán nincs jelölve) \\
\hline
\end{tabular}

4. TÁBLÁzat A DHV kezelésében lévö épületek a Salétrom utcán. Feloldása a 2. ábrán látható számkódoknak

\begin{tabular}{|l|l|}
\hline \multicolumn{1}{|c|}{ Név } & \multicolumn{1}{c|}{ Foglalkozás } \\
\hline Kerekes István & kocsivizsgáló lakatos \\
\hline Molnár Erzsébet & takarítónő \\
\hline Czura Ábel & villamos kalauz \\
\hline Kiss Elek & villamos kalauz \\
\hline Reményik Erzsébet & villamos kalauz \\
\hline Gulácsi Miklós & kovács segéd \\
\hline Rácsai Sándor & pályamunkás \\
\hline Hamza József & előmunkás \\
\hline
\end{tabular}

5. TÁBLÁZAT A DHV és DNyBV telepein 1944. június 2-án szolgálatteljesités közben meghalt alkalmazottak névsora ${ }^{17}$

${ }^{17}$ Debreceni Köztemető 1944-es temetőfőkönyv. 


\begin{tabular}{|l|l|l|}
\hline \multicolumn{1}{|c|}{ A kár leírása } & \multicolumn{1}{c|}{ Mennyiség } & \multicolumn{1}{c|}{ Pályaszám } \\
\hline elpusztult mozdony & 1 darab & 5092 \\
\hline elpusztult motorkocsi & 5 darab & $2,5,16,17,22$ \\
\hline elpusztult pótkocsi & 2 darab & 102,107 \\
\hline súlyosan megrongálódott motorkocsi & 2 darab & 19,24 \\
\hline tönkrement sínautóbusz & 1 darab & 354 \\
\hline súlyosan megrongálódott sínautóbusz & 2 darab & 353,355 \\
\hline kis mértékben sérült, javítandó motorkocsi & 4 darab & $8,9,18,21$ \\
\hline kis mértékben sérült, javítandó pótkocsi & 3 darab & $106,122,123$ \\
\hline fővonalon tönkrement pályatest & 205 folyóméter & - \\
\hline Késes utcai vágányon tönkrement pályatest & 94 folyóméter & - \\
\hline Kossuth utcai vonalon tönkrement pályatest & 60 folyóméter & - \\
\hline pályatest a Salétrom utcai telepen & 488 folyóméter & - \\
\hline tönkrement felsővezeték & 1600 folyóméter & - \\
\hline
\end{tabular}

6. TÁBLÁZAT A Debreceni Helyi Vasút Rt. (DHV) által elszenvedett gördülöanyag-, pálya- és felsövezeték kára a Debrecen ellen végrehajtott első légitámadás során (Forrás: MNL-HBML XI.105/a 38. cs.)

\begin{tabular}{|l|l|l|}
\hline \multicolumn{1}{|c|}{ A kár leírása } & \multicolumn{1}{|c|}{ Mennyiség } & \multicolumn{1}{c|}{ Pályaszám } \\
\hline elpusztult vonali vasúti mozdony (377-es típus) & 3 darab & $101,103,104$ \\
\hline elpusztult közúti vasúti mozdony & 2 darab & 2,3 \\
\hline elpusztult személykocsi („AB” és „C” típusú) & $1-1$ darab & 2,53 \\
\hline elpusztult fedett teherkocsi („G” típusú) & 1 darab & 303 \\
\hline elpusztult tartálykocsi („R” típusú) & 2 darab & 502299,503308 \\
\hline megsérült személykocsi („AB” és „C” típusú) & 7 darab & $1,51,52,54,55,56,57$ \\
\hline megsérült poggyászkocsi („DF” típusú) & 3 darab & $101,102,103$ \\
\hline megsérült fedett teherkocsi („,G” típusú) & 9 darab & $17,18,21,36,47,56,301,308,575$ \\
\hline megsérült tartálykocsi (,R” típusú) & 10 darab & $\begin{array}{l}502868,502880,551674,502857, \\
502300,502853\end{array}$ \\
\hline megsérült sínautóbusz & & M1, M2, M3, M4 \\
\hline megsérült motorkocsi & 4 darab & M11 \\
\hline megsérült pótkocsi („CD” típusú) & 1 darab & 21,22 \\
\hline tönkrement pályatest & 2 darab & - \\
\hline
\end{tabular}

7. TÁBLÁZAT A Debreceni-Nyirbátor Helyiérdekü Vasút (DNyBV) elszenvedett gördülöanyag-, pálya- és felsővezeték kára a Debrecen ellen végrehajtott elsö légitámadás során (Forrás: MNL-HBML XI.105/a 38. cs.) 


\begin{tabular}{|l|l|}
\hline \multicolumn{1}{|c|}{ Kárcsoport } & \multicolumn{1}{|c|}{ A kár mértéke pengőben } \\
\hline A DHV teljes ingatlankára & 829252 \\
\hline A DHV teljes üzemi berendezéskára & 403425 \\
\hline A DHV vasúti pályatestén keletkezett károk & 111000 \\
\hline A villamos felsővezeték rendszerben keletkezett károk & 18000 \\
\hline A DHV gördülőanyagában keletkezett károk & 1079000 \\
\hline A DNyBV teljes ingatlankára & 1176154 \\
\hline A DNyBV teljes üzemi berendezéskára & nincs adat \\
\hline A DNyBV vasúti pályatestén keletkezett károk & 104640 \\
\hline A DNyBV gördülőanyagában keletkezett károk & 1060700 \\
\hline ÖSSZESEN & $\mathbf{4 7 8 2 ~ 1 7 1}$ \\
\hline
\end{tabular}

8. TÁBLÁZAT A Salétrom utcai telepet ért károk mértéke 1944-es pengö árfolyamon (Forrás: MNL-OL, Z 1624)

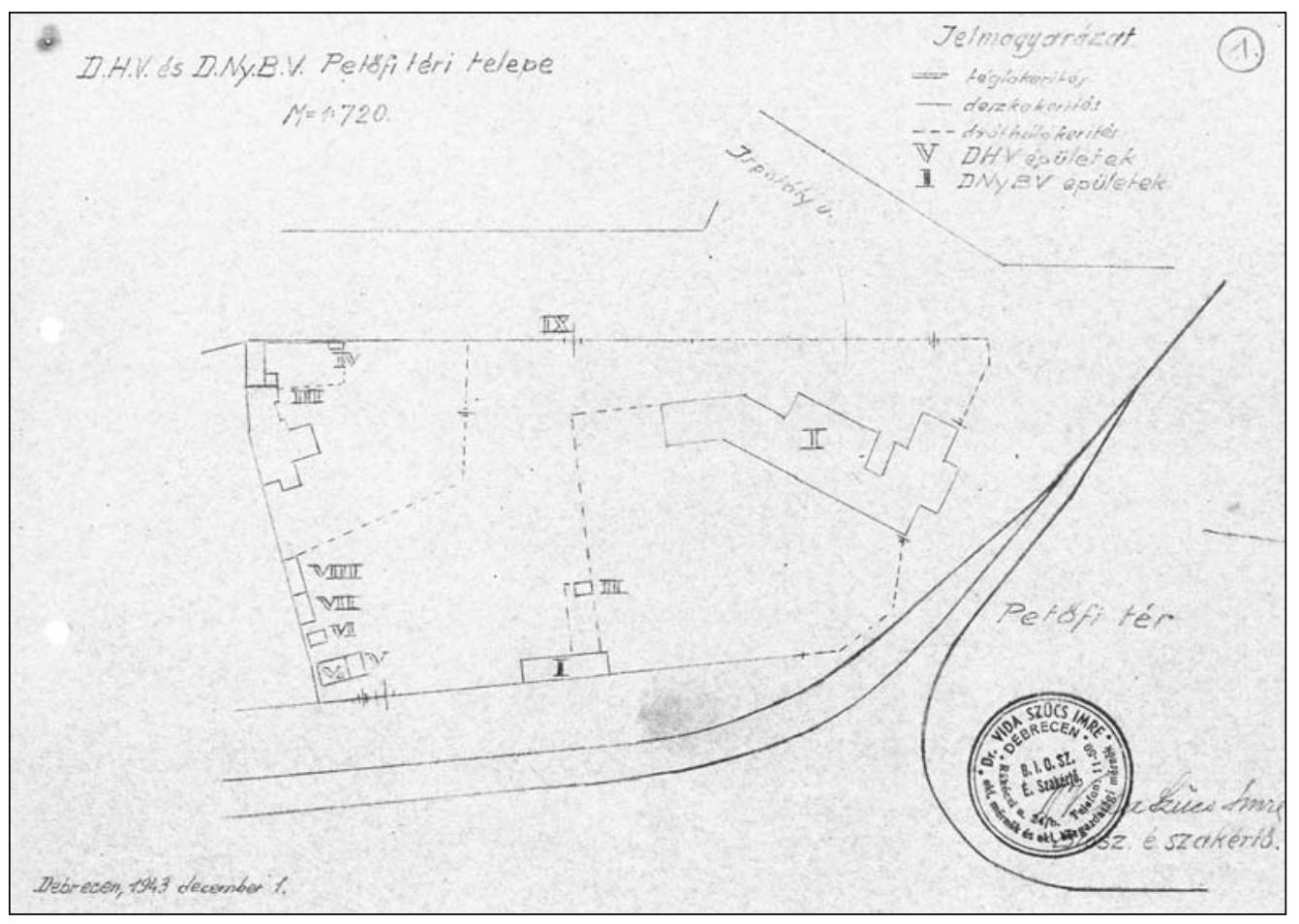

1. KÉP A DHV és DNyBV közös, Petöfi téren állt igazgatósági épületének helyszinrajza (Forrás: MNL-OL, Z 1624) 


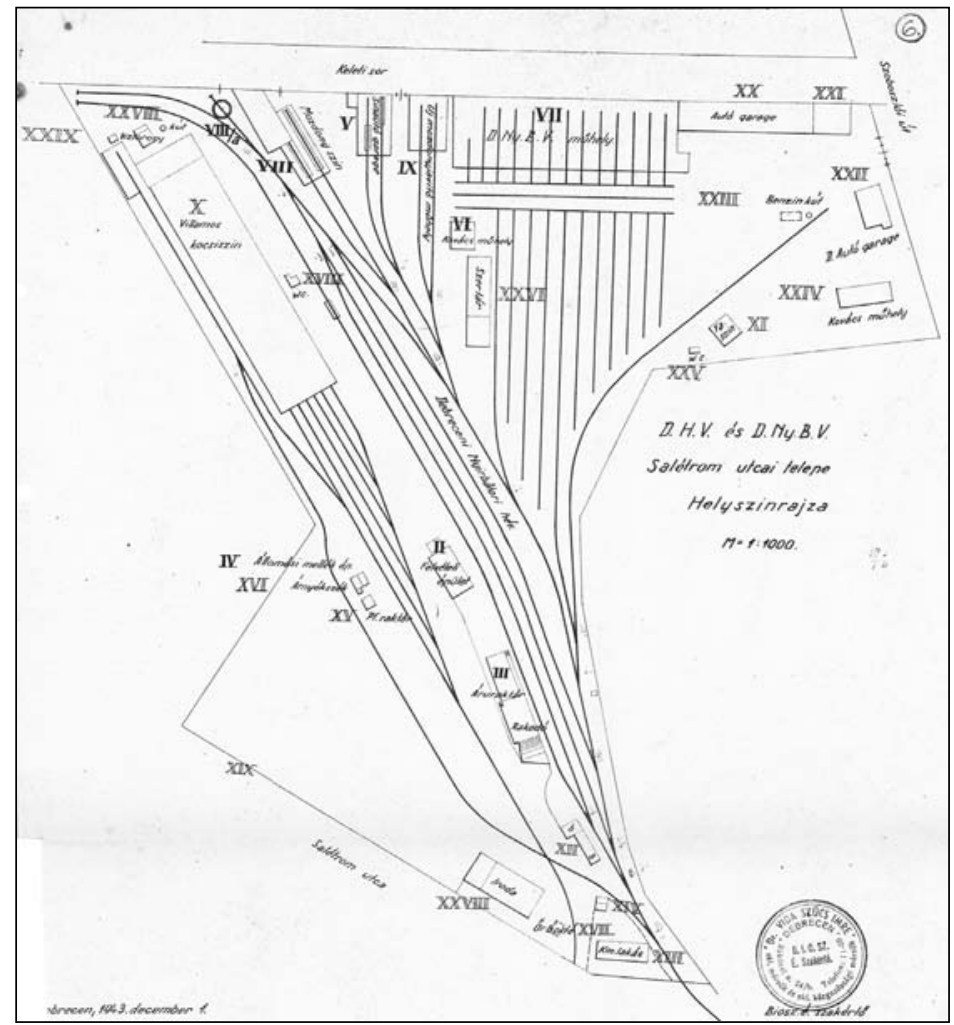

2. KÉP A DHV és a DNyBV által közösen használt Salétrom utcai telep helyszinrajza. Az I-IX közötti római számok a DNyBV által használt épületeket jelölik. A X-XXX közötti római számok pedig a DHV létesítményeit mutatják (Forrás: MNL-OL, Z 1624)

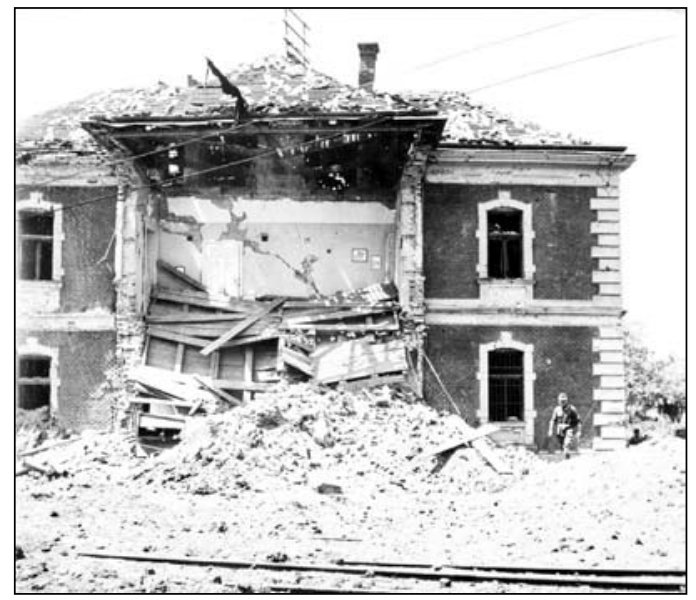

3. KÉP $A D H V$ és $D N y B V$ közös, Petöfi téren állt igazgatósági épületének maradványai 1944. június 2-án (Forrás: magángyüjtemény) 